\title{
viewpoint
}

\section{Science and fundamentalism}

\author{
A strategy on how to deal with anti-science fundamentalism
}

\author{
Massimo Pigliucci
}

$\mathrm{T}$ here has been much talk about fundamentalism of late. To most people, the word conjures up images of Islamic fundamentalism in the wake of the $9 / 11$ terrorist attacks against the USA, the ongoing war in Iraq, or the suicide bombings in the Middle East, London, Madrid and elsewhere. However, beyond what seems to be a 'clash of civilizations', there is another, home-made strain of fundamentalism, right at the heart of Western democratic societies, that is affecting science and its relationship to society in a way that may have dire long-term consequences.

The Oxford Dictionary of the Social Sciences defines fundamentalism as "a movement that asserts the primacy of religious values in social and political life and calls for a return to a 'fundamental' or pure form of religion" (Calhoun, 2002). Of course, religious fundamentalism has always had a history of antagonism with science and-even before the birth of modern science during the Enlightenment-with philosophy, humanity's age-old proven method to exercise critical and rational thinking to solve problems and pursue knowledge. In its broadest sense, however, fundamentalism is a form of ideological intransigence, which is not limited to religion, but includes political or social positions as well-for example, some extreme positions taken by 'environmentalists' or animal-rights activists.

In the USA, the modern version of this old conflict between science and religious fundamentalism is epitomized by the infamous Scopes trial. In 1925, John Scopes, a high-school science teacher in Dayton (TN, USA), was charged with illegally teaching Charles Darwin's theory of evolution (Larson, 1997; Pigliucci, 2002). This battle is still being fought; for example, in D over (PA, USA) at the time of writing, a court is deciding the legitimacy of teaching 'intelligent design'-a form of creationism-alongside the theory of evoIution in public schools. These relentless attacks by religious fundamentalists on one of the grandest theories of science are also taking place in natural history museums all over the USA. Museum directors have begun to train their staff in how to deal with creationists who challenge displays of evolution, advising them to retreat when the debate turns aggressive (Dean, 2005). Europeans, who are more secular, are not exempt from this recurrent debate. In July this year, Cardinal Christoph Schönborn, the archbishop of Vienna (Austria), wrote an article in which he castigated evolution as a scientific dogma and maintained that some form of guidance or intelligent design is evident in evolution (Schönborn, 2005).

\section{In its broadest sense... fundamentalism is a form of ideological intransigence, which is not limited to religion, but includes political or social positions...}

However, even in the USA, creationism is certainly not the only battleground between fundamentalism and science and, in some respects, it is not even the most crucial one. The current administration under President George W. Bush, for example, has systematically overruled or ignored scientific findings in areas ranging from global warming to drug safety, to affirm their ideologically determined set of priorities (Powell, 2002; Wadman, 2005). Europeans have their own problems with dogmatic thinking too, al beit arising from a different historical and cultural background. Consider the often-irrational positions taken by the Green parties, pro-life groups and environmental groups in Germany and England who indiscriminately reject stem-cell research or genetically engineered crops. O $r$ the fact that Italy has become the most restrictive European country on matters of stem-cell research and in vitro fertilization, largely owing to the strong influence of the Catholic Church in Italian internal political affairs.

$\mathrm{n}$ this article, how ever, I do not focus on specific controversies, but rather on what I consider to be a largely unappreciated dimension of the problem. It seems to me that a lot of the debates surrounding the science-society-religion cultural triangle and the ensuing problems are caused by a failure on the part of scientists and science educators-and hence the media, elected officials and the public at large- to appreciate two crucial philosophical points. These are: the distinction between methodological and philosophical naturalism; and the distinction between what 'is' and what 'ought' to be; that is, between matters of fact and value judgements. It is exactly this ignorance of the philosophical aspect of modern science that confuses the borders between science, religion and society, and which lies at the heart of scientists' difficulties in coping with attacks by fundamentalists of all kinds.

W hile I am certainly not as naive as to suggest that simply explaining these two points to colleagues and the public will 


\section{soience\& society}

\section{It is exactly this ignorance of the philosophical aspect of modern science that confuses the borders between science, religion and society...}

suffice to instantly 'solve' the so-called 'culture wars', I am confident that this is a good place to start a much-needed discussion that should be pursued in search of a long-term reconciliation between science and religion. I hope that by exploring these two philosophical issues, this article will provide scientists and educators with two formidable, intellectual and educational weapons in their fight against fundamentalist claims. I should also warn the reader that the following treatment glosses over several subtleties of the philosophical debate that still occupy professional philosophers. Nonetheless, I am convinced that the main points are both clear enough and highly relevant to the debate on how to deal with fundamentalism, so as to deserve a much wider presentation than has been the case so far.

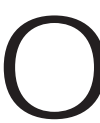

ne of the basic fears of religious fundamentalists who challenge the teaching of evolution, be they 'young-earth' creationists, 'old-earth' creationists or the slightly more sophisticated crowd of 'intelligent design' supporters (Scott, 1997), springs from the idea that the teaching of evolution sets us on a slippery slope that inevitably ends with atheism. Leaving aside the fact that many scientists can be both religious and believe in evolution, and the obvious point that atheism is a legitimate philosophical position that-in a pluralistic society-ought to receive the same degree of respect as any other metaphysical school of thought, 'slippery slope' arguments are logically fallacious (Epstein, 1999). The fallacy lies in the fact that most people-including, alas, prominent science popularizers such as Richard Dawkins-do not make the subtle but crucial distinction between methodological and philosophical naturalism.

Naturalism, broadly speaking, is the idea that there is only nature and that the supernatural realm and phenomena do not exist. As a philosophical position, it has a long history of elaboration and debate. Philosophical naturalism, then, is the strong metaphysical position that there is, as a matter of fact, no such thing as the supernatural nor a higher being, which obviously characterizes any individual who considers themselves an atheist. Methodological naturalism, however, is a metaphysically more modest claim. It takes the position that while there may be a supernatural realm or being, it does not enter and need not be invoked in any discussions of scientific findings (Forrest, 2000). For the methodological naturalist, scientific explanations of the world around us are naturalistic by definition, or else science would not have produced a set of reliable theories and empirical methods to work with and build on. This is why the most embarrassing question one can ask a proponent of intelligent design is: if I gave you a million dollars to set up a scientific research programme, what experiments would you pursue with the grant? There is no possible answer.

The crucial point here is that scientists are by definition methodological naturalists; however, they do not have any specific commitment to philosophical naturalism aside from their own metaphysical views. In other words, science does not necessarily demand atheism, as feared by the fundamentalists. How can we explain this to the general public? O ne way is to point out that most people are methodological naturalists when it comes to everyday life. Suppose your car does not start today: how do you react to such an annoying occurrence? Most probably you will not invoke a supernatural explanation, nor will you attempt to have the car exorcised by a priest. Instead, regardless of your religious convictions, you will take it to a mechanic, assuming-methodologically-that there must be something physically wrong with the vehicle. Moreover, even if the mechanic is not able to find the problem and fix your car, you will persist in the reasonable belief that there must be something physically out of place, with no supernatural implications or intervention required. You will shrug your shoulders, grudgingly pay the bill, and go in search of a new car or another mechanic. That is exactly what scientists do, and are required to do by their profession-no more, no less.

There is, therefore, a good reason why many scientists are religious (Larson \& Witham, 1997), and it is a mistake-both in terms of public relations and from a philosophical standpoint-to present the

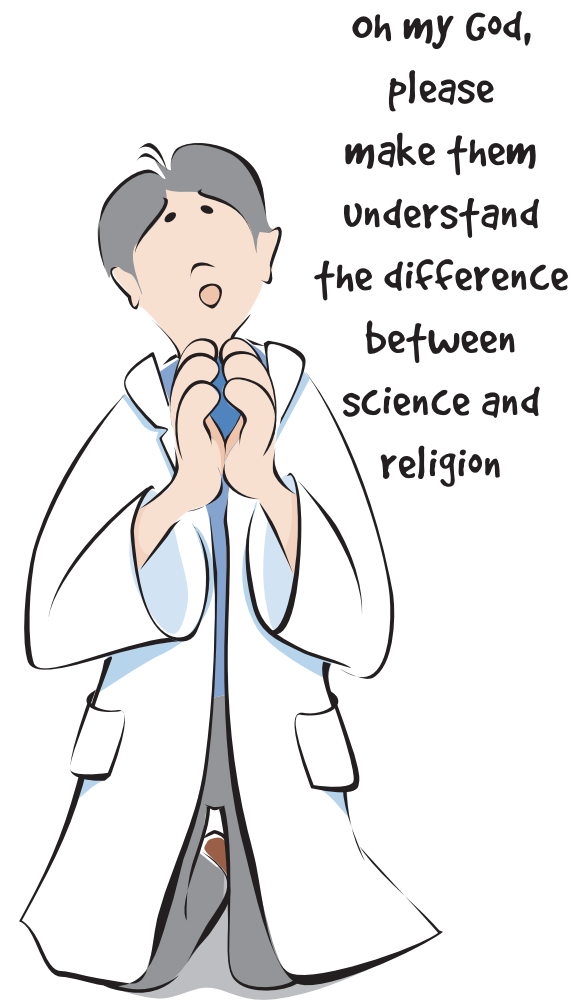

scientific worldview as one that necessarily and inevitably leads to atheism. Science can neither afford, nor does it need, a head-on confrontation with religion. This confrontation does need to occur, however, whenever religious ideologues make unsupported, a priori claims about the natural world, as is often the case with creationists. Adhering to the biblical view that Earth was created a few thousand years ago in six days and that God punished a sinful humanity with a worldwide flood, or invoking the necessity of an intelligent designer to explain how bacterial flagella evolved is, to paraphrase the philosopher Jeremy Bentham, nonsense on stilts- nonsense that needs to be vigorously fought by scientists and science educators. This still leaves plenty of room for a peaceful coexistence of science and religion when both sides recognize and respect the distinction between methodological and philosophical naturalism.

M any controversies between scientists and ideological fundamentalists (the word here indicating a broader context than just the religious one) are rooted in another common misconception, one that philosophers often 
refer to as the 'naturalistic fallacy'. The eighteenth-century Scottish philosopher David Hume first described this fallacyalthough he did not name it-in A Treatise of Human Nature (1739). Hume wrote about his puzzlement when encountering philosophical essays that began by considering matters of fact (what is) but which then somehow shifted to discussions of matters of value (what ought to be), without making the link explicit, nor justifying it in any reasonable way. This failure is prominent in the European debates on the use of genetically modified plants in agriculture, or in the ongoing debate on the ethics of research with human embryonic stem cells.

\section{... science does not necessarily demand atheism, asfeared by the fundamentalists}

The idea is not, of course, that there is no connection between facts and values, but rather that such a connection is anything but automatic, and that it needs to be justified. So, for example, a scientist can be intellectually interested in pursuing fundamental research on the properties of human embryonic stem cells or of genetically engineered crops, without this implying that the very act of carrying out such research necessarily entails a certain ethical position; that is, the scientist in question cannot automatically be labelled a 'Nazi' or an anti-environmentalist. Of course, there are limits to what scientists can do in the pursuit of knowledge; the atrocious experiments conducted on concentration-camp inmates, or the infamous Tuskegee experiment that left poor black sufferers of syphilis untreated to study the progression of the disease, are rightly considered intolerable. But no scientist in his or her right mind would even think about such experiments, let alone propose it to a grant review panel.

By the same token, how ever, the scientist must be aware that it is society at large that decides what level of public funding is allocated to a particular field of research, and even more importantly what sort of applications are acceptable from an ethical standpoint. In other words, the scientist does not need to cry 'anti-intellectualism' every time there is a legitimate public discussion about ethical standards in science. And if society decides that destroying human embryos to harvest stem cells is unacceptable, then the scientist has to adapt his research accordingly.

A better way to envisage the relationship between science and society is that the two are interconnected but in multiple and negotiable ways. The sociologist Peter W eingart describes this as an increasingly tighter coupling of science and society (W eingart, 2001). O n the one hand, science should be free as much as possible to pursue fundamental research in all areas of human knowledge, both for its own sake and because of the potentially positive consequences for society. On the other hand, scientists cannot be the sole arbiters of ethical decisions about what sort of science and its applications is acceptable by society at large, although of course scientists do have a special dual role as both informed experts and participating citizens in any such decision. As Hume would put it, there may be a connection between what is and what ought to be, but it has to be reasonably fleshed out in every specific case.

\section{... it must beclear to both scientists and the public at large that ethical decisions are simply too important to be simplistically derived from observations of what is'natural'}

Again, the challenge often comes down to explaining this in a way that is clear and understandable without having to mandate that everybody should take a course in philosophy-although the latter is not necessarily a bad idea. A good starting point are obvious cases where the 'is-ought' connection can be clearly rejected by any sane person, scientist or not. To use one of many available examples, science has demonstrated that it is 'natural' - it is a matter of fact-that males of some mammalian species, such as lions, kill a female's offspring from another male before taking her as a mate. This finding certainly does not imply that the study of behavioural ecology somehow leads to the justification of such actions for humans, i.e. the 'ought' simply does not follow the 'is'. Therefore, we should fund research in potentially controversial areas, just because we need as

\section{... we desperately need people who understand thescope, power and especially the limits of the scientific enterprise}

much information as possible to make intelligent decisions. But it must be clear to both scientists and the public at large that ethical decisions are simply too important to be simplistically derived from observations of what is 'natural'.

$\mathrm{S}$ cientists and science educators, when faced with irrational attacks against science, usually respond by clamouring for more and better science education. However, there is evidence that increasing science literacy not only will be insufficient, but also may have little or no effect if it is not accompanied by similar efforts to teach critical thinking and the philosophy of science (Walker et al, 2002; Johnson \& Pigliucci, 2004). The problem is that too much pre-college and even introductory-level college science education focuses on factual knowledge at the expense of broad conceptual issues, especially in the biological sciences. Obviously, we want our students and the population at large to be clear on some fundamental scientific facts; but, more importantly, we desperately need people who understand the scope, power and especially the limits of the scientific enterprise. Such understanding is crucial for the functioning of modern democracies, in which science has an ever-increasing role in everyday life.

The fact is, the teaching of critical thinking and the understanding of the nature of science are more properly-or at least equally - seen as the domains of philosophy, and require philosophers as well as scientists to be engaged in the response to fundamentalism. Moreover, as I have tried to argue above, both anti-intellectualism and anti-science fundamentalism are rooted in issues of ethics and religion, again the proper domain of philosophy, and areas in which scientists usually find themselves unprepared and uneasy. We need not turn scientists into philosophers, nor can we pretend that the general public can become knowledgeable of the depth of scientific and philosophical inquiry. What we can and need to do-urgently-is to promote a wide, interdisciplinary effort to educate scientists, science educators 
and the public at large about the science-society-religion triangle and the borders between each faction. Modern societies evolved when science and reason freed humanity from superstitions and religious dogmas and our developed societies have become increasingly dependent on scientific and technological progress to solve its manifold social and environmental problems. Attacks by fundamentalist ideologues therefore threaten nothing but the future of modern civilization.

\section{ACKN O W LED GEMENTS}

I thank J. Banta, O. Bossdorf and D. Futuyma for comments on a previous draft of themanuscript.

\section{REFERENCES}

Calhoun C (ed) (2002) Dictionary of the Social Sciences. O xford, UK: O xford U niversity Press Dean C (2005) Challenged by creationists, museums answer back. The N ew York Times, Sep 20, pF1. www.nytimes.com

Epstein RL (1999) Critical Thinking. Belmont, CA, USA: Wadsworth
Forrest B (2000) M ethodological naturalism and philosophical naturalism: clarifying the connection. Philo 3: 7-29

Hume D (1739) A Treatise of Human N ature. N orton D, N orton M (eds; 1978) N ew York, NY, USA: Clarendon

Johnson M, Pigliucci M (2004) Is knowledge of science associated with higher skepticism of pseudoscientific claims? Am Biol Teach 66: 536-548

Larson El (1997) Summer for the Gods. The Scopes Trial and America's Continuing Debate over Science and Religion. N ew York, NY, U SA: Basic Books

Larson EJ, W itham L (1997) Scientists are still keeping the faith. N ature 386: 435-436

Pigliucci M (2002) D enying Evolution: Creationism, Scientism, and the $\mathrm{N}$ ature of Science. Sunderland, M A, USA: Sinauer

Powell K (2002) Bush climate-change plan gets cool response. N ature 420: 595

Schönborn C (2005) Finding design in nature. The New York Times, Jul 7, pA23. www.nytimes.com Scott EC (1997) Antievolution and creationism in the U nited States. Annu Rev Anthropol 26: 263-289

Wadman M (2005) D rug agency accused of political bias. N ature 437: 179
Walker W R, H oekstra SJ, Vogl RJ (2002) Science education is no guarantee of skepticism. Skeptic 9: 24-27

Weingart P (2001) Die Stunde der Wahrheit? Weilerswist, Germany: Velbrück

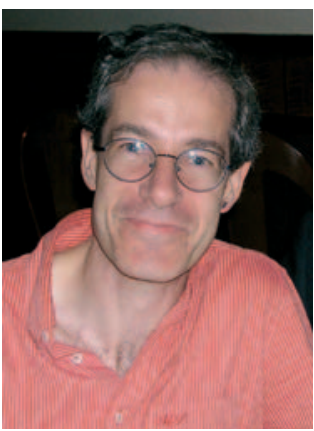

Massimo Pigliucci is a professor in the Departments of Ecology \& Evolution and Philosophy at the State University of New York (Stony Brook, NY, USA). E-mail: pigliucci@genotypebyenvironment.org

doi:10.1038/sj.embor.7400589 